\title{
Gerentes versus propietarios: análisis comparativo de eficiencia en la industria de la construcción
}

\section{Resumen}

Martín Dutto Giolongo

Profesor FCE (UNL)

E-mail:mdutto@fce.unl.edu.ar

Marcos Gallacher Profesor Universidad del CEMA

E-mail: gmg@cema.edu.ar

Palabras clave

- eficiencia

- estructura de propiedad

- control
El problema de la "separación de la propiedad y control" ha interesado desde hace tiempo a investigadores especializados en organización empresarial. Por un lado, el hecho de que gerentes profesionales (y no los propios capitalistas) administren la empresa requiere que controles adicionales deben ser implementados a fin de que estos gerentes no disipen la renta que resulta posible generar. Sin embargo, puede también argumentarse que los gerentes profesionales -si bien generan costos de control- pueden tener habilidades que no tienen los propios capitalistas de la empresa. El "mercado gerencial" en definitiva permite elegir aquel cuyas características mas se acercan a lo requerido. Este trabajo compara eficiencia de empresas administradas por propietarios, con aquellas donde a-priori puede esperarse mayor separación entre la propiedad de los recursos y el gerenciamiento de estos (sociedades formales). La muestra de datos empleada corresponde a empresas constructoras contratistas del Estado. Los resultados econométricos no permiten detectar diferencias significativas de eficiencia entre ambos tipos de empresa. 


\section{Abstract}

The problem of "separation of ownership and control" has long interested researchers specializing in business organization. The fact that professional managers (and not the capitalists themselves) manage the business requires that additional controls have to be implemented in order that these managers not dissipate the rent that can be generated. However, it can also be argued that professional managers -although requiring control costs- have abilities lacking in the firms capitalists. Indeed, the "managerial market" allows a wider range of abilities to be tapped. This paper compares efficiency of firms managed by owners, as compared to those where -priori- a greater separation of ownership and control may

Key words

- efficiency

- ownership structure

- control be expected. The data set used corresponds to construction firms working on government contracts. No differences in efficiency between the two groups of firms is detected. 